\title{
WORKPLACE FRIENDSHIP AMONG MINIA UNIVERSITY HOSPITALS' NURSES
}

\author{
By \\ Abd EL Latief OK ${ }^{1}$, Refeai SA ${ }^{2}$, Mohammed ES ${ }^{2}$, Emam SA $^{2}$ and Ghazawy ER ${ }^{2}$, \\ ${ }^{1}$ Department of Public Health and Occupational Medicine, ${ }^{2}$ Department of Public Health \\ and Preventive Medicine, Faculty of Medicine, Minia University. \\ Corresponding author: Abd El LatiefOK: Omnia.Kamal@mu.edu.eg
}

\begin{abstract}
Introduction: Friendship at work is a natural occurrence in the workplace, so examination of the manifestation of friendship in the workplace is a critical issue for organizations. Nurses play a central role in healthcare, linking their communication effectiveness to team, organization, and patient outcomes. Nurse care is one of the most important predictors of patient satisfaction, which linked to patient treatment plans. The profession remains burdened by numerous stressors which can result in turnover. The current study focuses on how friendships at work may develop commitment behaviors to combat turnover intention in nursing. Aim of work: To determine the relation between work place friendship, personal and work characteristics among nurses working at Minia University Hospitals and to assess its effect on turnover intention and job performance. Materials and methods: It is a cross sectional study included all nurses who work at Minia University Hospitals during the study period from December 2018 to January 2019 (476 nurses). Workplace Friendship Scale, job performance and turnover intention were measured. Results: In the Friendship Opportunity Dimension (FOD) subscale, there was a significant difference in scores between males and females. There were no effects of marital status or age group regarding workplace friendships. There was a significant effect of department and work shift on opportunity and prevalence of friendship. Friendship opportunity had an effect on job performance ( $\beta=0,150$ and $\mathrm{p}=0.005$ ), however it had no significant effect on turnover intention. On the other hand, friendship prevalence had a significant effect on both job performance and turnover intention scale $(\beta=0,195$ and $p=0.0001$, $\beta=-0,170$ and $p=0.002$ respectively).Conclusion: There were good interpersonal relationships between nurses
\end{abstract}


working at Minia University Hospitals. Friendships seemed to be more developed among males. Night shifts had more opportunities for friendships at the workplace. Workplace friendship influenced job performance and turnover intention

Keywords: Friendship, Work, Nurses, Turnover intention and Job performance

\section{Introduction}

Positive interpersonal interactions and relationships at the workplace are deemed important in any organization as they can influence the happiness and well-being of workers and affect their overall productivity (Bandiera et al., 2008 and Stoetzer et al., 2009). Workplace friendship is imminent as we spend more time in the workplace (lee and Ok, 2011; Asgharian et al. 2013) and it has become a norm which either increases the sustainability of the workplace or ruins it (Morrison, 2004). Workplace friendship is a multidimensional and complex phenomenon; it involves people from different gender, age and cultures (Sias, 2005). Thus, examination of friendship in the workplace is an important issue for organizations (Ong, 2013).

Several individual and organizational benefits can be derived from workplace friendship. Workplace friendship affects employees' work-related attitudes which enhance organizational outcomes such as support from others, reduced stress, increased job satisfaction and is linked to work effectiveness (Berman et al., 2002; Song, 2007 and Hwang et al., 2012).

The job stress of healthcare providers has been recognized as a serious social problem (Jones et al., 1988) Continuous exposure to high levels of job stress remains a concern not only because it involves ongoing personal suffering (Taylor et al., 2005; Marin et al., 2011) but also because it may threaten the quality of patient care (Bovier and Perneger, 2003; Karadzinska-Bislimovska et al., 2014). Nurses play an important role in demonstrating the efficiency of the healthcare organization they are the closest and most frequent contact with patients during their hospital stays. The quality of nursing has a main impact on patients' safety, as well as physical and psychological health outcomes both throughout and after hospitalization (Othman et al., 2017).

Despite the importance of nurses to health care delivery, the profession remains burdened by numerous stressors which can result in turnover. The provision of social support within 
nurses' work relationships has positive results in several studies (Ray and Apker, 2011). Therefore, this study attempted to identify the factors influencing nurses' workplace friendship and investigate how friendship affects job outcomes.

\section{Aim of work}

To determine the relation between workplace friendship, personal and job related characteristics among nurses working at Minia University Hospitals and to assess its effect on turnover intention and job performance.

\section{Materials and methods}

Study design: This is a crosssectional study

Place and duration of the study: The study was conducted among nurses working at Minia University Hospitals, Minia Governorate, Egypt; during the period from December 2018 to January 2019. Minia University Hospitals are tertiary health care facilities. They provide the main health care services to the community in Minia Governorate.

Study sample: The sample consists of all nurses working in the selected workplaces during the study period. The total number of nurses was 512, 476 agreed to participate in the study. The remaining 36 (7\%) nurses refused to participate. The response rate was $93 \%$.

\section{Study methods:}

\section{1- Self administrated questionnaires} were distributed to the nurses in their working units. The average time taken to interview each nurse was 15 minutes. A pilot study was carried out on 10 nurses to test the feasibility and the applicability of the questionnaire, and to identify the most suitable time to collect data. The results of the pilot study were included in the study results because no changes were applied to it. The questionnaire collected data about nurses' demographic characteristics (age, gender and marital status), work characteristics (department and work shift)

\section{2- Measuring instruments:}

a- Workplace Friendship Scale (WFS) was measured using the 12 itemed scale developed by Nielsen et al. (2000). It is a 5 point Likert scale, ranging from strongly disagree (1) to strongly agree (5) for the positive items. The negative items were rated as from strongly disagree (5) to strongly agree (1). The scale includes 2 dimensions; Friendship Opportunity Dimension (FOD) (6 items) and Friendship Prevalence Dimension (FPD) (6 items). On the original scale, the reliability 
of the six items in each subscale regarding the internal consistency with Cronbach's alpha results was .84 and .89 for the friendship "opportunities" and "prevalence" subscales, respectively (Morrison, 2004 and Dickie, 2009). Question number 12 of FPD was removed as according to Bader et al. (2013) the rate of reliability of FPD increased after removal of this item.

b- Job performance was measured using nine items developed by Goodman and Svyantek (1999) with three items each. All items were presented with a 7-point Likert scale with a range from (1) strongly disagree to (7) strongly agree. The overall Cronbach's alpha for this instrument was 0.81 (Kim, 2014).

c- Turnover intention was assessed by a three-item scale developed by Colarelli (1982), this scale is a 5-point Likert scale ranging from (1) strongly disagree to (5) strongly agree. The internal consistency of this three-item scale ranged from .75 to .82 (Shuck et al., 2011 and Kim, 2012).

\section{Consent}

Informed consent was obtained from the nurses. Confidentiality of the data was strictly maintained through a code number on the questionnaire.

\section{Ethical approval}

The study protocol was approved by the Ethics Committee of the Faculty of Medicine, Minia University.

\section{Data management}

Statistical analysis was carried out using the Statistical Package for Social Sciences (SPSS) version 20. Quantitative data were presented as mean and standard deviation. Student's $t$ test and One way Anova were used. A multivariate analysis was also undertaken. Statistical significance was set at $\mathrm{P}$ - value $<0.05$. 


\section{Result}

Four hundred and seventy six nurses were included in this study. Their age ranged from 20 to 59 years [Mean $\pm \mathrm{SD}(31.8 \pm 9.5)$ ].

Table 1: The mean and standard deviation of items of workplace friendship scale

\begin{tabular}{|l|c|c|}
\hline Items & Mean & SD \\
\hline & & \\
I have formed strong friendships at work (FPD). & & \\
I have the opportunity to know my coworkers (FOD). & 4.20 & 0.95 \\
I have the opportunity to develop close friendships at my workplace (FOD). & 4.08 & 0.92 \\
I am able to work with my coworkers to solve problems (FOD). & 4.05 & 0.99 \\
I am able to see my coworkers under one condition; I look forward to my job & 4.03 & 0.93 \\
(FPD). & 3.96 & 1.00 \\
Communication among employees is encouraged by my organization (FOD). & 3.77 & 1.02 \\
I feel I can trust many coworkers (FPD). & 3.60 & 1.06 \\
I can be confident in people at work (FPD). & 3.45 & 1.07 \\
I have a social life with coworkers outside the workplace (FPD). & 3.38 & 1.18 \\
Informal talk is tolerated by my organization as long as the work is & 3.12 & 1.17 \\
completed (FOD). & 2.85 & 1.21 \\
In my organization; I have the opportunity to talk informally and visit others & & \\
(FOD). & & \\
\hline
\end{tabular}

FOD: Friendship opportunity dimension;

FPD: Friendship prevalence dimension

Table 1 showed that the highest mean was $4.200 .95 \pm$ in item "I have formed strong friendships at work." followed by "I have the opportunity to know my coworkers." with a mean of 4.080.92 \pm . The second-lowest mean was in item "Informal talk is tolerated by my organization as long as the work is completed." with a mean of 3.121.17 \pm , followed by "In my organization I have the opportunity to talk informally and visit with others" with the lowest mean of 2.851.21士. 
Table 2: Comparison between personal characteristics and subscales of workplace friendships.

\begin{tabular}{|l|c|c|c|}
\hline \multicolumn{1}{|c|}{ Variables } & No & $\begin{array}{c}\text { FOD } \\
\text { Mean } \pm \text { SD } \\
\text { p-value }\end{array}$ & $\begin{array}{c}\text { FPD } \\
\text { Mean } \pm \text { SD } \\
\text { p-value }\end{array}$ \\
\hline Age groups & & & \\
Less than or equal 29 & 256 & $3.7(0.72)$ & $3.6(0.75)$ \\
30-39 years & 119 & $3.7(0.69)$ & $3.7(0.66)$ \\
40-49 years & 63 & $3.7(0.56)$ & $3.7(0.64)$ \\
50-59 years & 38 & $3.6(0.63)$ & $3.7(0.81)$ \\
Total & 476 & $3.7(0.72)$ & $3.7(0.72)$ \\
& & 0.9 & 0.8 \\
& & $\mathrm{~F}=0.88$ & $\mathrm{~F}=0.24$ \\
\hline Gender & 141 & $3.9(0.71)$ & $3.7(0.72)$ \\
Male & 335 & $3.6(0.65)$ & $3.6(0.72)$ \\
Female & 476 & $\mathbf{0 . 0 0 0 1 * *}$ & 0.1 \\
Total & $\mathrm{t}=4.6$ & $\mathrm{t}=1.3$ \\
& & & $\mathrm{~F}=0.19$ \\
\hline Marital status & & $4.1(1.7)$ & $4.4(1.6)$ \\
Single & 119 & $4.4(1.5)$ & $4.7(1.5)$ \\
Married & 349 & $3.9(1.2)$ & $4.3(1.7)$ \\
Divorced & 5 & $5.7(0.6)$ & $5.6(0.8)$ \\
Widowed & $3.7(0.72)$ & $3.7(0.72)$ \\
Total & & 0.1 & 0.1 \\
& & $\mathrm{~F}=1.11$ & $\mathrm{~F}$ \\
\hline
\end{tabular}

- FOD: Friendship Opportunity Dimension;

-FPD: Friendship Prevalence Dimension

- t: t-test for Subscales of Workplace Friendship Scale with gender

- F: (ANOVA) of Subscales of Workplace Friendship Scale with different age groups and marital status **: Highly statistically significant

Table 2 showed that as regards the gender: in the FOD subscale, there was a statistically significant difference in scores between males and females (3.90.71 \pm ) and (3.60.65 \pm ) respectively, but there was no significant difference as regards FPD. Also there was no significant difference for age and marital status on the presence 
or opportunity of friendships at the workplace subscale.

Table 3: Analysis of variance (ANOVA) of Workplace Friendship Scale (WFS) subscales and nurses' work characteristics.

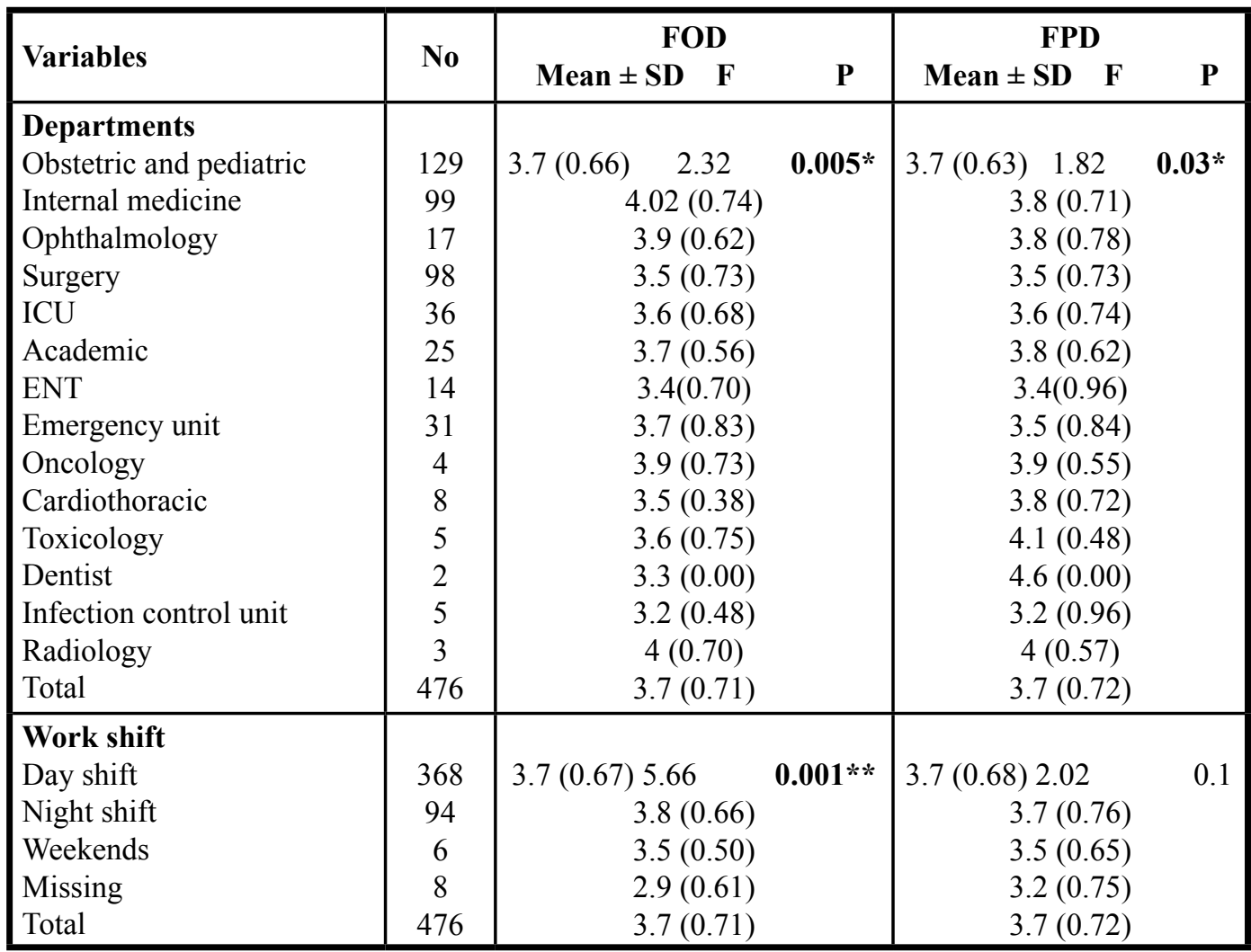

FOD: Friendship Opportunity Dimension;

-FPD: Friendship Prevalence Dimension

ICU: Intensive care unit

*: Statistically significant

**: Highly statistically significant

Table 3 showed that there was a statistically significant difference between different departments for both subscales of the WFS, the Opportunity for Friendships at the Workplace subscale $(\mathrm{F}=2.32, \mathrm{p}=0.005)$ and the Prevalence of Friendships at the Workplace subscale $(\mathrm{F}=1.83, \mathrm{p}=0.03)$. Internal Medicine and Radiology departments had more opportunities for friendships at the workplace (4.020.74 \pm ) and $(40.70 \pm)$, respectively. There was a statistically significant difference on the work shifts for opportunity for friendship $(F=5.66, p=0.001)$. Night shifts had more opportunities for friendships at the workplace (3.80.66 \pm ) while there was no 
effect of work shifts on the PFD at the Workplace subscale.

Table 4: Linear regression analysis for the effects of workplace friendship on Turnover intention and Job performance.

\begin{tabular}{|l|c|c|c|c|c|c|}
\hline \multirow{2}{*}{} & \multicolumn{6}{|c|}{ Dependent Variables } \\
\cline { 2 - 7 } & \multicolumn{3}{|c|}{ Turnover intention } & \multicolumn{3}{c|}{ Job performance } \\
\hline $\begin{array}{l}\text { Independent } \\
\text { variables }\end{array}$ & $\boldsymbol{\beta}$ & $\mathbf{p}$-value & $\mathbf{R}^{2}$ & $\boldsymbol{\beta}$ & $\mathbf{p}$-value & $\mathbf{R}^{2}$ \\
\hline $\begin{array}{l}\text { Friendship } \\
\text { opportunity }\end{array}$ & -0.104 & 0.05 & 0.2 & 0.150 & $\mathbf{0 . 0 0 5 *}$ & 0.3 \\
\hline $\begin{array}{l}\text { Friendship } \\
\text { prevalence }\end{array}$ & -0.170 & $\mathbf{0 . 0 0 2} *$ & $\mathrm{x}$ & 0.195 & $\mathbf{0 . 0 0 0 1 * *}$ & $\mathrm{x}$ \\
\hline
\end{tabular}

*: Statistically significant

**: Highly statistically significant

As shown in Table 4, friendship opportunity and friendship prevalence were significantly and positively related to job performance $(\beta=0.150, \mathrm{p} 0.005)$ and $(\beta$ $=0.195, \mathrm{p} 0.0001)$, respectively. While friendship prevalence was significantly and

\section{Discussion}

In the working ward, potency is completely associated with job satisfaction in three dimensions, benefit and promotion, human relationship and job environment. The nurse who has higher efficiency demonstrates that her friendship network is rich in structural hoes and will take the advantage of the opportunities to get support to induce her job. Also her job satisfaction is going to be promoted (Seers, 1989).

The current study revealed that according to Workplace Friendship Scale, forming strong friendships at work and having the opportunity to know coworkers were the most prominent items (Table 1). This coincides with what reported by (Alexandre, 2018) from São Paulo, Brazil. On the other hand having opportunity to talk informally and visit others were the least available items (Table 1) which differs with Roberts et al, 2012 from United States of America who concluded that in developed countries they pay more attention to make work environment 
more comfortable and decreasing stressors as nursing stress has an impact on the individualıs health, safety, and well-being as well as on healthcare organizations. Therefore, having close friends with whom one meets of at least once per day are needed to produce positive effects on job stress.

Markiewicz and Kausilas (2000) found that women had fewer friends. Women had mainly male friends at their workplace, compared to men having male friends. Many studies found significant relationships between gender and workplace friendships (Odden and Sias, 1997; Tse et al., 2008; Carmeli et al., 2009 Morrison, 2009). In line with this, the current study found males had higher mean score than females in the opportunity for friendships at the workplace (Table 2). On the other hand, Berman et al. (2002) found a positive strong orientation toward the workplace friendships, but they did not vary significantly by gender.

The Opportunity for Friendships at the Workplace subscale revealed a significant difference among various departments (Table 3). Internal medicine and Radiology department had more opportunities for friendships at the workplace and this coincided with
Amarneh et al, 2010 who stated that Jordanian nurses who worked in the Internal Medicine and Dialysis units reported having more friendship opportunities and social support from coworkers. The present study revealed that night shifts had more opportunities for friendships at the workplace (Table $3)$. Also this came in accordance with Sung and Sang, 2016 from Korea who studied the effects of hospital workers' Friendship Networks on job stress and reported that night shift favored friendships opportunities.

Our work demonstrated that friendship opportunity was significantly and positively related to job performance $(\beta=0,150$ and $p=0.005)$ (Table 4$)$ and this is in agreement with what was-detected by (Özlem et al, 2016) from Turkey that friendship opportunity has a positive significant effect on job satisfaction $(\beta=0,579$ and $p=0.0001)$. Ting and Ho (2017) found that workplace friendship directly influences job performance.

On the other hand friendship prevalencehadasignificanteffect on both job performance and turnover intention scale $(\beta=0,195$ and $p=0.0001)$ and $(\beta=-0,170$ and $p=0.002)$, respectively (Table 4); and this was in agreement with a study done by (Riordan, 2013) 
in England and detected that the effect of friendship prevalence on job involvement and turnover intention is great $(\beta=0,157$ and $p=0.005)$ and $(\beta=$ $0,190$ and $p=0.0001)$, respectively. $\mathrm{He}$ also stated that spending more time and building trust between employees play a greater role to identify themselves with their job. Asgharian et al., 2013 found that workplace friendship showed a $21.2 \%$ impact on turnover intention.

Conclusion: There were good interpersonal relationships between nurses working in Minia University hospitals. Friendships seem to be more developed among males. Night shifts had more opportunities for friendships at the workplace. Workplace friendship influences job performance and turnover intention. Depending on these findings, it can be concluded that friendship opportunity and friendship prevalence are critical variable for the organizations So, any organization should support informal relationships and provide relaxed atmosphere which is very important for employee to be satisfied with their jobs. This will be reflected on overall outcome of the organization.

\section{Conflict of interest}

The authors declared that there is no conflict of interest.

\section{Funding}

No sources of funding.

\section{Acknowledgment}

We are grateful to all nurses for their participation in the study. Also we would like to thank the hospital administrators for their help.

\section{References}

1. Alexandre PB (2018): Nursing leadership and its relationship with the hospital work environment; Acta Paul Enferm; 31(2):187-93

2. Amarneh BH, Abu Al-Rub RF and Abu AlRub RF (2010): Co-workers' support and job performance among nurses in Jordanian hospitals. Journal of Research in Nursing; 15(5) :391-40.

3. Asgharian R, Yusoff R, Yaser Mazhari M, Mardani A and Soltan E (2013): Examining the effect of workplace friendships and Job Embeddedness on Turnover Intention (The Case of Mashhad as a Tourist Destination in Iran). International Journal of Business and Management Invention; 2 (7): 17-25.

4. Bader HA, Hashim IH and Zaharim NM (2013): Workplace Friendships among Bank Employees in Eastern Libya. Digest of Middle East Studies; 22(1): 94-116.

5. BalabanÖ and Özsoy E (2016): Effects of Workplace friendship on individual outcomes 2016. Available at https://www.researchgate. net/publication/301349685_Effects_of_ Workplace_friendship_on_individual_ outcomes

6. Bandiera O, Barankay I and Rasul I (2008): Social capital in the workplace: Evidence on its formation and consequences. Labour Economics; 15(4): 724-48.

7. Berman E, West $P$ and Richter N (2002): Workplace relations: Friendship patterns and 
consequences according to managers. Public Administration Review; 62(2): 217-30.

8. Bovier A and Perneger V (2003): Predictors of work satisfaction among physicians. European Journal of Public Health; 13: 299-305.

9. Carmeli A, Brueller D and Dutton E (2009): Learning behaviors in the workplace: The role of high-quality interpersonal relationships and psychological safety. Systems Research and Behavioral Science; 26(1): 81-98.

10. Dickie C (2009): Exploring workplace friendships in business: Cultural variations of employee behavior. Research and Practice in Human Resource Management; 17(1):35-43.

11. Goodman A and Svyantek J (1999): Personorganization fit and contextual performance: Do shared values matter. Journal of Vocational Behavior; 55(2):254-75. doi:10.1006/ jvbe.1998.1682

12. Hwang M, Seo Y, Kim S and Kang K (2012): Workplace Friendship and Organizational Effectiveness of Hospital Employees. Health Policy and Management; 22(4): 654-75.

13. Jones JW, Barge BN, Steffy BD, Fay LM and Kunz LK, et al. (1988): Stress and medical malpractice: Organizational risk assessment and intervention. Journal of Applied Psychology; 73: 727-35.

14. Karadzinska-Bislimovska J, Basarovska V, Mijakoski D, Minov J, Stoleski S, et al. (2014): Linkages between workplace stressors and quality of care from health professionals> perspective-Macedonian experience. British Journal of Health Psychology; 19: 425-41.

15. Kim W (2014): An Examination of Work Engagement in Selected Major Organizations in Korea: It's Role as a Mediator between Antecedents and Consequences (Pennsylvania (Doctoral dissertation). Available at :https:// etda.libraries.psu.edu/paper/20601/

16. Lee J and Ok C (2011): Effects of workplace friendship on employee job satisfaction, organizational citizenship behavior, turnover intention, absenteeism, and task performance.
Paper presented at the 16th Graduate Students Research Conference, Houston, Texas.

17. Marin F, Lord C, Andrews J, Juster P, Sindi S, et al. (2011): Chronic stress, cognitive functioning, and mental health. Neurobiology of Learning and Memory; 96: 583-595.

18. Markiewicz D and Kausilas M (2000): Friendships of women and men at work: Job satisfaction and resource implications. Journal of Managerial Psychology; 15(2):161-84.

19. Morrison L (2009): Are women tending and befriending in the workplace? Gender differences in the relationship between workplace friendships and organizational outcomes. Sex Roles; 60: 1-2.

20. Morrison R (2004): Informal Relationships in the Workplace: Associations with Job Satisfaction, Organizational commitment and turnover intentions. New Zealand Journal of Psychology; 33(3):114-28.

21. Nielsen K, Jex M, and Adams A (2000): Development and validation of scores on a two dimensional Workplace Friendship Scale. Educational and Psychological Measurement; 60(4): 628-43.

22. Odden M and Sias M (1997): Peer communication relationships, psychological climate, and gender. Communication Quarterly; 45(3), 153-66.

23. Ong L (2013): Workplace Friendshıp, Trust in Coworkers and Employees Actual Problems of Economics; 140 (2): 289-94.

24. Othman N, Ghazali Z and Sa'ari Ahmad S (2017): work engagement in nursing: do job demands and resources really matter? Sci Int (Lahore);29(2):411-15

25. Ray B and Apker J (2011): Stress, burnout, and supportive communication. In T. L. Thompson, R. Parrott, \& J. F. Nussbaum (Eds.), The Routledge handbook of health communication, 2nd ed. (pp. 428-440). New York, NY: Routledge.

26. Riordan R, Christine M and Griffeth R (1995): The opportunity for friendship in the workplace: 
An underexplored construct. Journal of Business and Psychology; 10 (2): 141-54.

27. Roberts R, Grubb $\mathrm{P}$ and Grosch W (2012): Alleviating job stress in nurses approaches to reducing job stress in nurses. Medscape. Available at: https://www. medscape.com/viewarticle/765974.

28. Seers A (1989): Team-member exchange quality: A new construct for role-making research. Organizational Behavior and Human Decision Processes; 43: 118-35.

29. Shuck B, Reio J and Rocco S (2011): Employee engagement: An examination of antecedent and outcome variables. Human Resource Development International; 14(4): 427-45.

30. Sias P (2005): Workplace relationship quality and employee information experiences. Communication Studies; 56(4): 375-95.

31. Song SH (2007): Workplace Friendship and Employees Productivity: LMX Theory and the case of the Seoul City Government. International Review of Public Administration; 11(1): 47-58.

32. Stoetzer U, Ahlberg G, Bergman P, Hallsten L and Lundberg I (2009): Working conditions predicting interpersonal relationship problems at work. European Journal of Work and Organizational Psychology; 18(4):424-41.

33. Sung YS and Sang GL (2016): Effects of Hospital Workers' Friendship Networks on Job Stress. PLoS One; 11(2): e0149428.

34. Taylor C, Graham J, Potts W, Richards M and Ramirez A (2005): Changes in mental health of UK hospital consultants since the mid-1990s. Lancet; 366: 742-44.

35. Ting $S$ and Ho M (2017): The Influence of Workplace Friendship, Job Involvement, and Organizational Identification on Job Performance: Administrative Staffs of Private Science and Technology Universities in South Taiwan as an Example. International Journal of Humanities and Social Sciences ;9 (6):46-57

36. Tse H, Dasborough M and Ashkanasy N (2008): A multi-level analysis of team climate and interpersonal exchange relationships at work. The Leadership Quarterly; 19(2): 195-211. 